\title{
INTRACELLULAR GROWTH AND TYPE VARIATION OF NEISSERIA GONORRHOEAE IN TISSUE CELL-CULTURES
}

\author{
SheENA A. WaITKINS AND J. FlynN \\ Department of Medical Microbiology, University of Sheffield, Sheffield, S10 2TN
}

\section{Plates XIII AND XIV}

EVEN today the cultivation of Neisseria gonorrhoeae on laboratory media may present difficulties. Despite a wide range of media, including those containing ascitic fluid or other native protein, the long-term cultivation of gonococci without spontaneous degradation to avirulent forms is almost impossible. The gonococcus can be maintained in a fully virulent form only by the selective transfer of type I (virulent) colonies (Kellogg et al., 1963).

The failure to infect small laboratory animals with the gonococcus has limited research, especially into the immune response of the host and the invivo behaviour of the organism. However, these disadvantages have been partly overcome by the use of tissue-culture cells to study the reactions of the cell to $N$. gonorrhoeae and the subsequent sensitivity of engulfed organisms to antibiotics (Thayer et al., 1957; Meyer-Rohn and Rohde, 1961; Rohde and Meyer-Rohn, 1961). Long-term cultivation, in which the gonococcus surviyed up to 88 days has been reported by Gavrilescu et al. (1966), who used a KB cell-line. Diena et al. (1971) developed a technique for assay of the antibacterial action of serum antibody against the gonococcus; they used monkeykidney cells infected with gonococci as an indicator system. Kenny and Aris (1969) claimed that after growth for $48 \mathrm{hr}$ in monkey-kidney tissue cultures, avirulent gonococci of types III and IV (Kellogg et al.) subcultured on laboratory medium yielded colonies of virulent types I and II.

We have studied the growth and stability of colonial types I and IV gonococci in mouse (3T3) and monkey (Vero and LLC-MK 2 ) tissue-culture cells.

\section{MATERIALS AND METHODS}

\section{Antibiotics}

Antibiotic solutions were made up in 100 -ml amounts in the following concentrations: vancomycin $\mathrm{HCl}$ (Lilly) $5 \mu \mathrm{g}$ per ml; penicillin (Vestric) 100 units per ml; streptomycin $100 \mu \mathrm{g}$ per $\mathrm{ml}$; nystatin $25 \mathrm{IU}$ per $\mathrm{ml}$. The solutions were dispensed in 0.5 -ml volumes per $1000 \mathrm{ml}$ of media used.

\section{Media}

Five per cent. lysed horse-blood agar: Columbia Agar Base (Oxoid) $39 \mathrm{~g}$, distilled water $1000 \mathrm{ml}$. Soak for $15 \mathrm{~min}$. Mix and autoclave at $121^{\circ} \mathrm{C}$ for $15 \mathrm{~min}$. Allow to cool to $55^{\circ} \mathrm{C}$ and then add $50 \mathrm{ml}$ of sterile horse-blood (Wellcome) lysed by repeated freezing and thawing. 
Difco GC Medium Base plus defined supplement (GCMB medium): Difco GC Medium Base $36 \mathrm{~g}$, distilled water $1000 \mathrm{ml}$. Heat to $70^{\circ} \mathrm{C}$ for $10 \mathrm{~min}$. then autoclave at $121^{\circ} \mathrm{C}$ for $15 \mathrm{~min}$. Allow to cool to $60^{\circ} \mathrm{C}$ and add $20 \mathrm{ml}$ of supplement.

Supplement: prepared by adding $1 \mathrm{ml}$ of solution 2 to $99 \mathrm{ml}$ of solution 1 and sterilising by Sietz filtration.

Solution 1. (A) Glutamine solution: $1 \mathrm{~g}$ of L-glutamine and $40 \mathrm{~g}$ of dextrose dissolved in $89 \mathrm{ml}$ of distilled water. (B) Ferric nitrate solution: $0.05 \mathrm{~g}$ of ferric nitrate dissolved in $10 \mathrm{ml}$ of distilled water. Add solution (A) to (B) (White and Kellogg, 1965).

Solution 2. Cocarboxylase $1 \mathrm{mg}$ in $50 \mathrm{ml}$.

Eagle's M.E.M. (single strength): deionised water $450 \mathrm{ml}$, Eagle's M.E.M. (Wellcome) $50 \mathrm{ml}$, foetal calf-serum (Biocult) $50 \mathrm{ml}$, sodium-bicarbonate 4.4 per cent. (Analar) $5 \mathrm{ml}$. For cell lines that required it, 1 per cent. Non-essential Amino Acids (Biocult) was added to the medium just before use.

Dulbecco solution, $p H 7 \cdot 3$ was made by adding $1 \mathrm{ml}$ of sterile 1 per cent. magnesium chloride solution and $1 \mathrm{ml}$ of sterile 1 per cent. calcium chloride solution to $100 \mathrm{ml}$ of Dulbecco A (Oxoid) which had been sterilised at $115^{\circ} \mathrm{C}$ for $10 \mathrm{~min}$.

Magnesium chloride solution: $\mathrm{MgCl}_{2} .6 \mathrm{H}_{2} \mathrm{O} 1 \mathrm{~g}, \mathrm{NaCl} 0.85 \mathrm{~g}$, distilled water $100 \mathrm{ml}$; autoclaved at $115^{\circ} \mathrm{C}$ for $10 \mathrm{~min}$.

Calcium chloride solution: $\mathrm{CaCl}_{2} 1 \mathrm{~g}, \mathrm{NaCl} 0.85 \mathrm{~g}$, distilled water $100 \mathrm{ml}$; autoclaved at $115^{\circ} \mathrm{C}$ for $10 \mathrm{~min}$.

\section{Test organism}

The strain of $N$. gonorrhoeae (no. 71/4508) used in these experiments was isolated from a patient attending the Sheffield Venereal-diseases Clinic and was initially grown on 5 per cent. lysed horse-blood agar with 1 per cent. vancomycin solution $5 \mu \mathrm{g}$ per $\mathrm{ml}$. It was identified by Gram's stain, a positive oxidase reaction, and fermentation of glucose but not maltose or sucrose. Fermentations were tested in a modified carbohydrate medium containing Difco GC Medium Base (GCMB) with 1 per cent. of the sugar (Flynn and Waitkins, 1972). After the strain had been shown to be pure it was preserved by " snap freezing" in liquid nitrogen with 1 per cent. glycerol peptone broth as suspending medium. By selective transfers on GCMB, colonial variants I and IV (Kellogg et al.) were isolated from this strain and incubated at $37^{\circ} \mathrm{C}$ for $18 \mathrm{hr}$ in an atmosphere of 5 per cent. $\mathrm{CO}_{2}$.

\section{Tissue-cell culture}

The tissue cell-lines used were $3 \mathrm{~T} 3$ mouse-fibroblast cells, Vero monkey-kidney cells, and LLCMK $_{2}$ (derived) monkey-kidney cells. For the 3T3 and LLCMK 2 cells, 1 per cent. nonessential amino acids was added to the Eagle's medium. The tissue cells were passaged weekly in $100-\mathrm{ml}$ medical-flat bottles containing the above medium plus penicillin 100 units per $\mathrm{ml}$, streptomycin $100 \mu \mathrm{g}$ per $\mathrm{ml}$, and nystatin $25 \mathrm{IU}$ per $\mathrm{ml}$ (Eagle, 1959). The monolayer was then broken up with versene, the cells were distributed in 2-ml volumes into tissue-culture tubes containing coverslips $(1 \times 4 \mathrm{~cm})$, the final cell suspensions being approximately $10^{5}$ cells per $\mathrm{ml}$. The tubes were sloped to form a monolayer on the coverslips and grown at $37^{\circ} \mathrm{C}$ for 3 to 4 days. Just before inoculation with $N$. gonorrhoeae, the overlay was poured off and the monolayer was thoroughly washed several times with warmed Dulbecco phosphate-buffered saline to remove extraneous antibiotics.

Each tissue-culture tube containing a 2-ml overlay of antibiotic-free Eagle's medium was then inoculated with $0.1 \mathrm{ml}$ of a suspension containing about $60 \times 10^{8}$ gonococci per ml, and incubated at $37^{\circ} \mathrm{C}$. From each tube $1 \mathrm{ml}$ of supernatant fluid was removed at $0,2,4$, $8,12,16,20$, and $24 \mathrm{hr}$ and the growth of $N$. gonorrhoeae was monitored by the Miles, Misra and Irwin (1938) method on 5 per cent. lysed horse-blood agar. Simultaneously coverslips from the corresponding tubes were thoroughly washed in phosphate-buffered saline to remove bacteria adherent to the tissue cells and were stained by Leishman's method. The supernatant fluid was also plated out on GCMB medium for colonial typing. 


\section{NeISSERIA IN TISSUE CELL-CULTURES}

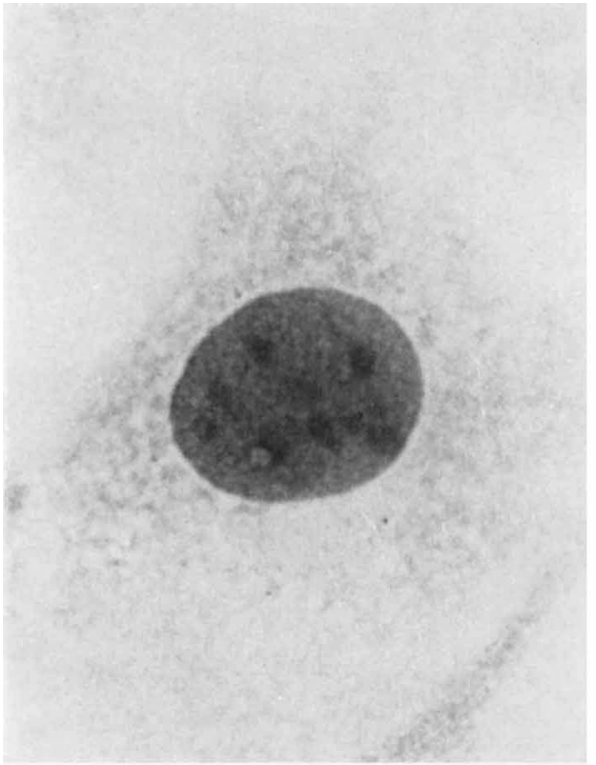

FIG. 2a.-Mouse-fibroblast 3T3 cell monolayer immediately after inoculation with Neisseria gonorrhoeae. No cytoplasmic inclusion of the organism can be seen. Leishman. $\times 700$.

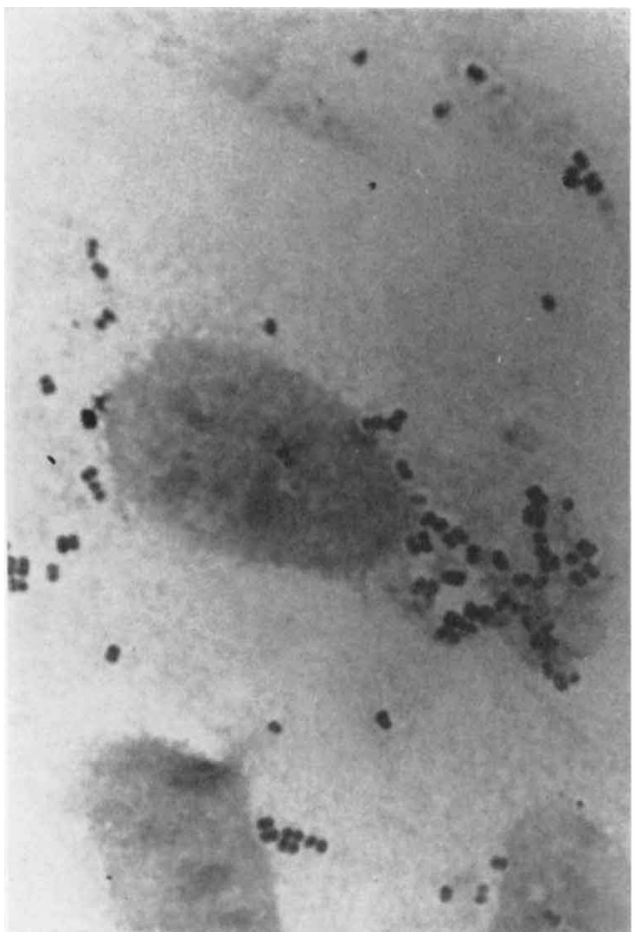

FIG. 2c.--Mouse-fibroblast 3T3 cell monolayer $8 \mathrm{hr}$ after inoculation with Neisseria gonorrhoeae showing maximum cytoplasmic inclusion of gonococci. Leishman. $\times 700$.

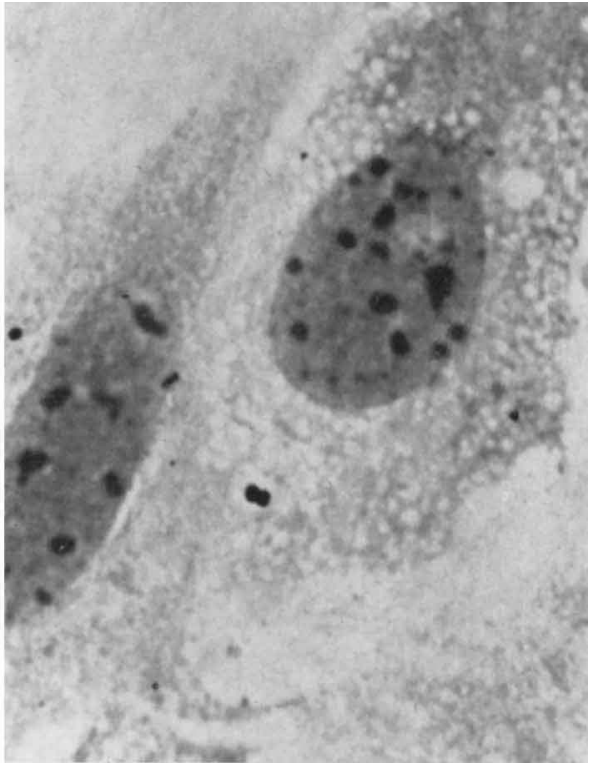

FIG. 2b.-Mouse-fibroblast 3T3 cell monolayer $2 \mathrm{hr}$ after inoculation with Neisseria gonorrhoeae showing the earliest sign of cytoplasmic inclusion of the organism. Leishman. $\times 700$.

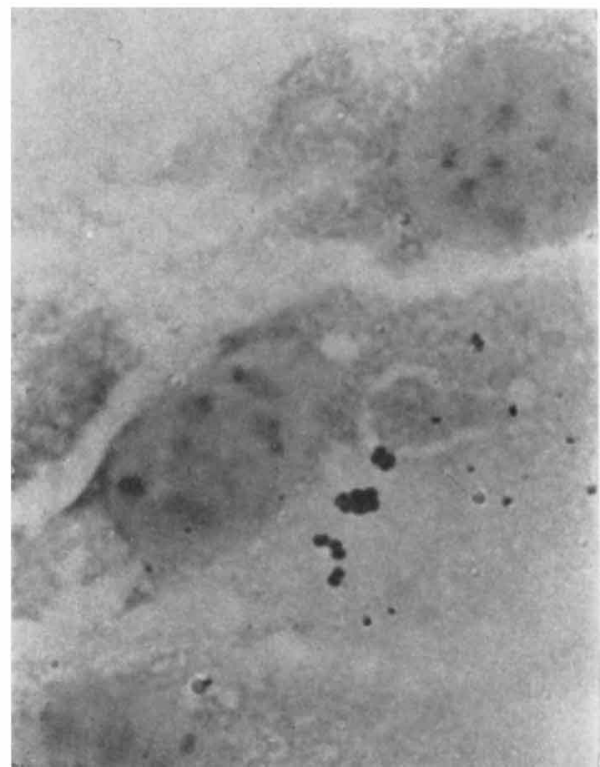

FIG. 2d.-Mouse-fibroblast 3T3 cell monolayer $24 \mathrm{hr}$ after inoculation with Neisseria gonorrhoeae, showing breakdown and death of the tissue cell with a few remaining intracellular gonococci. Leishman. $\times 700$. 
NEISSERIA IN TISSUE CELL-CULTURES

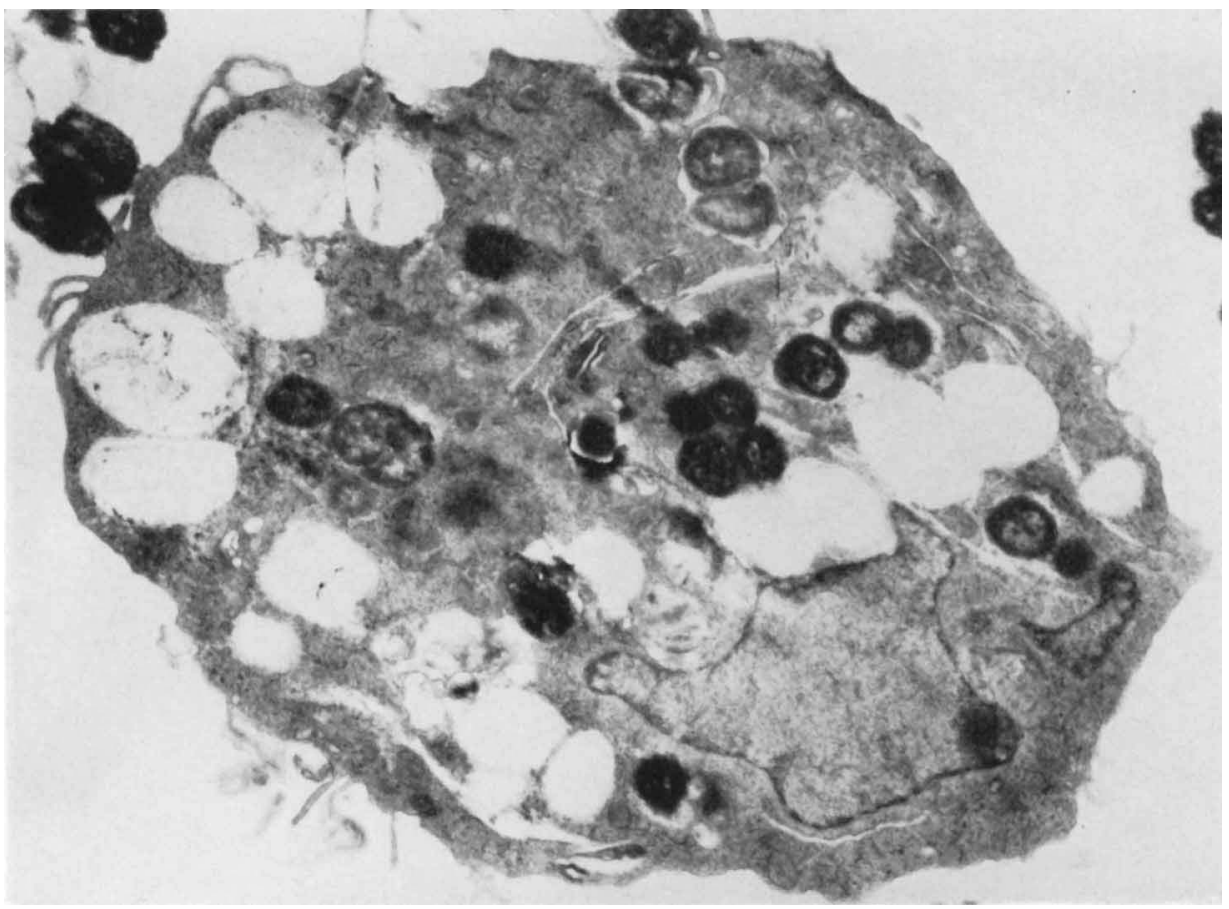

FIG. 3a.--Electron-microscopic photographs of monkey-epithelial LLCMK $\mathrm{L}_{2}$ cells $8 \mathrm{hr}$ after inoculation, showing gonococci within the tissue cell. EM. $\times 7500$.

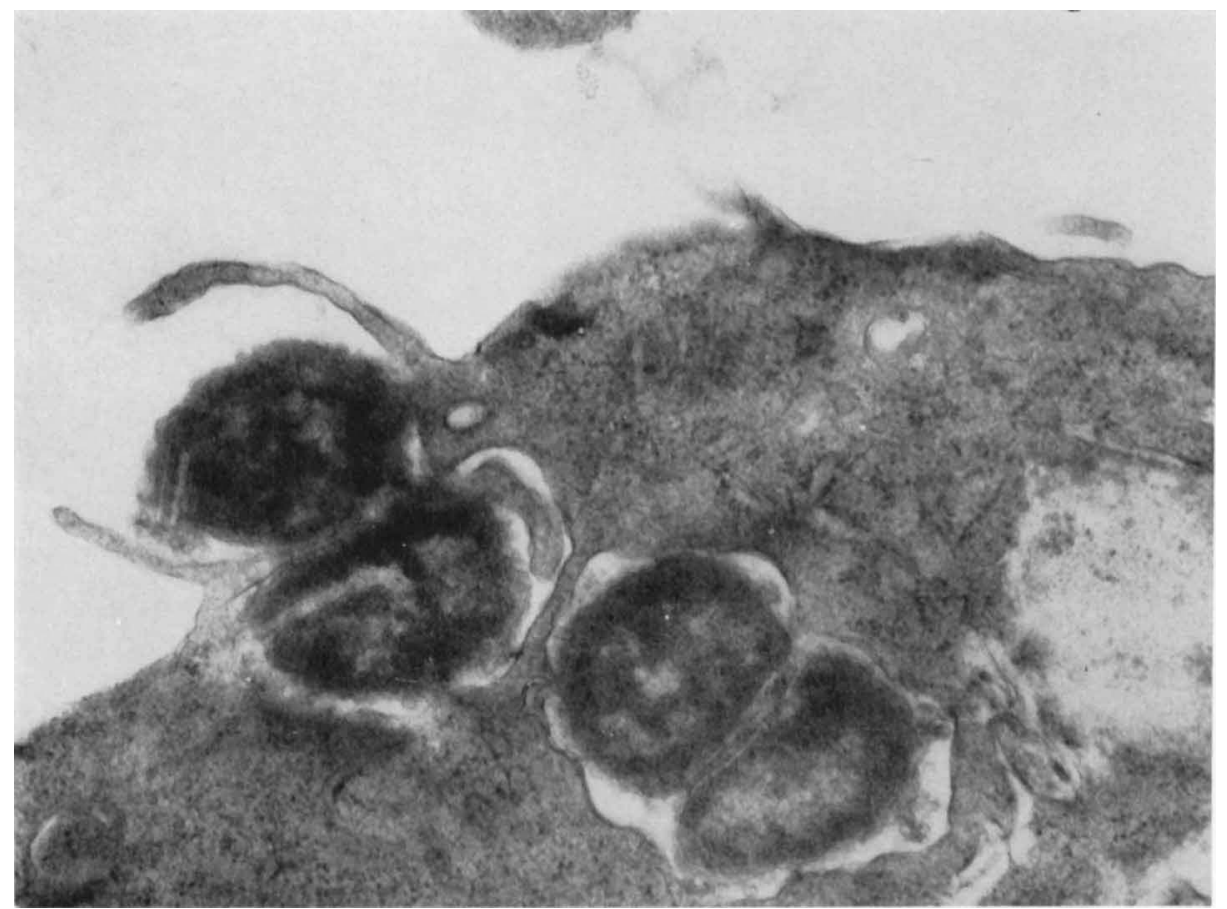

FIG. 3b.--Electron-microscopic photographs of monkey-epithelial LLCMK 2 cells, showing cytoplasmic pseudopodia engulfing a pair of gonococci and a typical diplococcus already within the cell. EM. $\times 15,000$. 


\section{Electron microscopy}

A preparation that had been incubating for $8 \mathrm{hr}$ was washed twice with warmed Dulbecco phosphate-buffered saline; versene was then added to break up the monolayer of cells. The dispersed cells were gently centrifuged at 400 r.p.m. for $4 \mathrm{hr}$ and fixed with 3 per cent. glutaralderhyde at $4^{\circ} \mathrm{C}$ for $2 \mathrm{hr}$. The resulting pellet was washed gently three times in sucrose-phosphate buffer over a period of $24 \mathrm{hr}$. The pellet was fixed in 2 per cent. unbuffered osmium tetraoxide, block-stained with 0.5 per cent. uranyl acetate $(p H 5.0)$, dehydrated with increasing concentrations of alcohol, and impregnated with Araldite. Sections were cut by an ultramicrotome and stained with Reynolds' lead citrate. An A.E.I. EM/81 electron microscope was used for viewing.

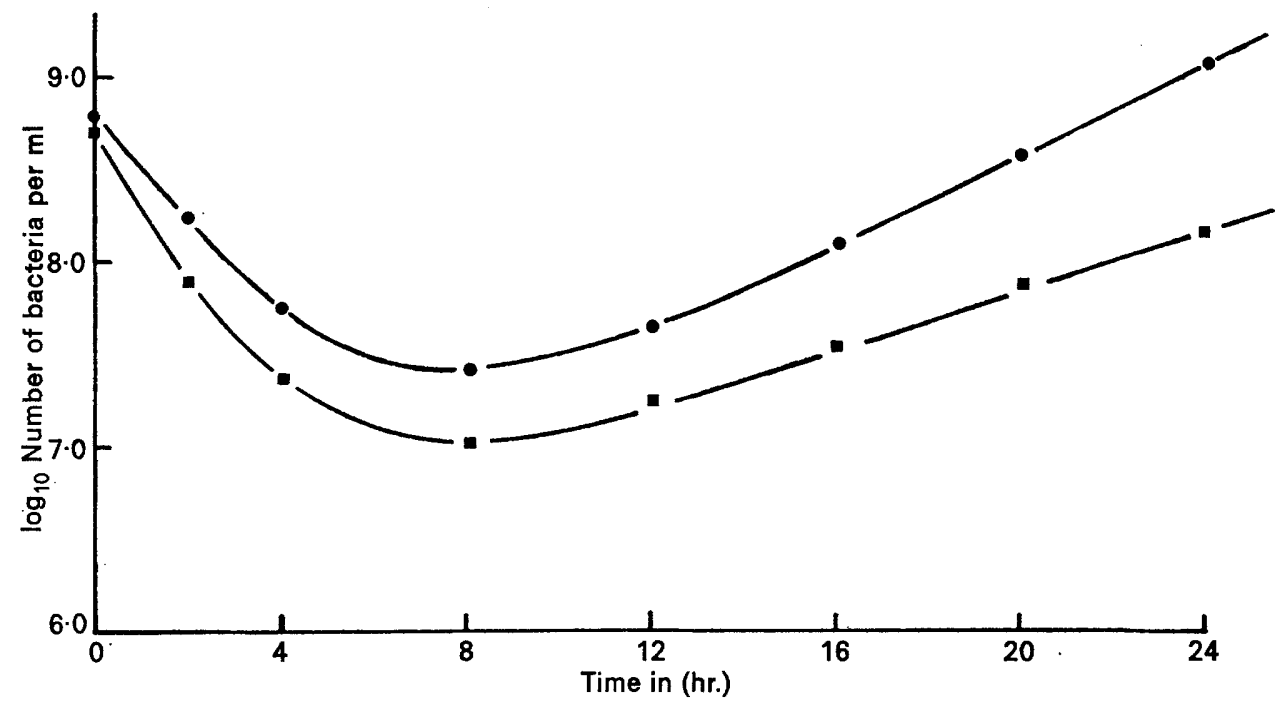

Fig. 1.-Growth of Neisseria gonorrhoeae in mouse-fibroblast 3T3 tissue-culture cells over a period of $24 \mathrm{hr}$.

\section{RESULTS}

Fig. 1 shows the number of $N$. gonorrhoeae in the overlay of 3T3 mouse fibroblast cells during a period of $24 \mathrm{hr}$. The number of viable bacteria was minimal at $8 \mathrm{hr}$. Gonococci could be seen to become progressively more abundant in the tissue cells over the same period, as seen by preparations of Leishman-stained cells (fig. $2 a-d$ ). Even after repeated vigorous washings with phosphate-buffered saline, the gonococci were not removed and therefore appeared to be within the cytoplasm of the tissue cells and not lying in intracellular areas or merely attached to the cell surfaces. The " haloed " effect, which could be seen as clear areas around the gonococci, may indicate the intracellular inclusions of these organisms.

To prove that $N$. gonorrhoeae were in fact intracellular, thin sections of 3T3, LLCMK microscope. In a cross-section of $\mathrm{LLCMK}_{2}$ cells $8 \mathrm{hr}$ after infection with gonococci (fig. $3 a$ ), diplococci could be seen in the process of being ingested into the cell. At higher magnification (fig. $3 b$ ) cytoplasmic pseudopodia 
extending from the epithelial cell and engulfing a gonococcus could be seen, with diplococci already ingested in the same field. Sections of the Vero and 3T3 cells at $8 \mathrm{hr}$ also showed the ingestion of the gonococci intracellularly. Organisms of types I and IV were ingested by the cell. To exclude extracellular multiplication of the organism as a possible explanation for their increase in the overlay, the following two experiments were made.

(i) The intracellular growth of $N$. gonorrhoeae was monitored in tissue cells killed by heating to $60^{\circ} \mathrm{C}$, in live cells, and in the appropriate tissue-culture medium. After $24 \mathrm{hr}$, viable gonococci could be recovered only from the live cell-cultures.

(ii) Rat serum, which is bactericidal for gonococci, was added to tissueculture cells containing $N$. gonorrhoeae. All extracellular organisms were killed and only after repeated washings with Dulbecco phosphate-buffer to clear the rat serum from the overlay was there a significant increase of viable organisms. This indicates that these organisms were "protected" from the rat serum within the cells (Flynn, 1972).

When grown for $24 \mathrm{hr}$ within tissue-culture cells, $N$. gonorrhoeae did not change from avirulent type IV to virulent type I or vice versa. Even when the overlay medium was changed every $24 \mathrm{hr}$ and the observation period extended to $96 \mathrm{hr}$ there was no change of type in either direction.

\section{Discussion}

In this series of experiments the tissue-culture cells rapidly ingested gonococci by phagocytic action. If this represents the action of cells within the mucous membrane of the urinary tract, it is quite possible that live gonococci may be protected from the therapeutic action of antibiotics and even from local antibodies. Cells containing surviving gonococci may be the most effective inocula in the transmission of the disease. Because of the 24-hourly changes of overlay medium, tissue cell-cultures are not a convenient method for maintenance of type I colonies; the snap-freezing method with liquid nitrogen is more useful (Ward and Watt, 1971). There seems to be no apparent reversion of type IV to the virulent type I, as Kenny et al. (1969) suggested; this is in accordance with the findings of Kellogg et al. (1963) that type IV organisms failed to infect human volunteers.

\section{SUMMARY}

Phagocytosis of Neisseria gonorrhoeae in tissue cell-cultures may protect it from the lethal action of bactericidal agents. Type reversal from avirulent to virulent gonococci was not observed. We believe that maintenance of type I organisms in tissue cultures is too tedious and that snap-freezing in liquid nitrogen is more convenient.

We wish to thank the Medical Research Council for financial assistance, Professor M. G. McEntegart for help in the preparation of this manuscript, Dr I. A. Carr and Mr P. Morris, Department of Pathology, Weston Park Hospital, for help with the electron microscopy, and Miss Ann Littlewood for technical assistance. 


\section{REFERENCES}

Diena, B. B., Wallace, R., Kenny, C. P., and Greenberg, L. 1971. A tissue culture technique for the assay of antibacterial immune sera. Can.J. Microbiol., 17, 13.

EAGLE, H. 1959. Amino acid metabolism in mammalian cell cultures. Science, N.Y., 130, 432.

Flynd, J., AND Waitkins, Sheena A. 1972. A serum-free medium for testing fermentation reactions in Neisseria gonorrhoeae. J. Clin. Path., 25, 525.

FLYNN, J. 1972. Studies on the factors which determine the resistance of small laboratory animals to infection with Neisseria gonorrhoeae. M.D. Thesis, University of Sheffield.

Gavrilescu, M., Lazar, M., Porojan, I., and Circiumarescu, T. 1966. Long term cultivation of $N$. gonorrhoeae in tissue culture. Br.J. Vener. Dis., 42, 171.

Kellogg, D. S., Jr, Peacock, W. L., JR, Deacon, W. E., Brown, L., and Pirkle, C. I. 1963. Neisseria gonorrhoeae. I. Virulence genetically linked to clonal variation. $J$. Bact., 85, 1274.

Kenny, C. P., AND ARIs, Barbara J. 1969. The infection of tissue cells in culture with Neisseria gonorrhoeae. Can. J. Publ. Hlth, 60, 34.

Meyer-Rohn, J., AND RoHDE, B. 1961. Phagocytierte Gonokokken in der Gewebekultur und ihr Verhalten gegenuber Penicillin. Hautarzt, 12, 373.

Miles, A. A., MisRA, S. S., AND IRWIN, J. O. 1938. The estimation of the bactericidal power of the blood. J. Hyg., Camb., 38, 732.

RohDe, B., AND MeYer-Rohn, J. 1961. Die Phagocytose von Neisseria gonorrhoeae in der Gewebekultur. Hautarzt, 12, 466.

Thayer, J. D., Perry, Miriam I., Field, Frances W., and Garson, W. 1957. Failure of penicillin, chloramphenicol, erythromycin and novobiocin to kill phagocytozed gonococci in tissue culture. Antibiotics A., 1956-1957, p. 513.

WARD, M. E., AND WATT, P. J. 1971. The preservation of gonococci in liquid nitrogen. $J$. Clin. Path., 24, 122.

Whrte, L. A., AND KellogG, D. S., JR 1965. Neisseria gonorrhoeae identification in direct smears by a fluorescent antibody-counterstain method. Appl. Microbiol., 13, 171. 